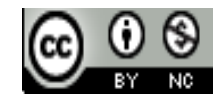

Jurnal Terapan Manajemen dan Bisnis is licensed under

A Creative Commons Attribution-NonCommercial 4.0 International License.

\title{
CONSIGNMENT INCOME RECOGNITION AND MEASUREMENT IN INDONESIA RETAIL COMPANIES
}

\author{
Zharunisa $^{1)}$, Priandaru Wahyu Hutomo ${ }^{2)}$, Amrie Firmansyah ${ }^{3)}$ \\ 1) Polytechnic of State Finance STAN, Jakarta, Indonesia \\ E-mail: zharunisa@gmail.com \\ 2) Polytechnic of State Finance STAN, Jakarta, Indonesia \\ E-mail: priandaru.wh@gmail.com \\ 3) Polytechnic of State Finance STAN, Jakarta, Indonesia \\ E-mail: amrie.firmansyah@gmail.com
}

\begin{abstract}
This study aims to review the consignment income recognition and measurement from the consignee. Up to now, there is no specific Indonesia Statement of Financial Accounting Standards (hereinafter referred to as PSAK) that regulates the recognition, measurement, and disclosure of consignment revenues. The PSAK used in this study refers to PSAK 23, 2017 on Corporate Revenues.

The research method used in this research is qualitative descriptive by comparing data obtained from direct observations in a company with theories and financial accounting standards related to consignment income. The population used in this study is the financial statements of 2017 from the retail sub-sector companies listed on the Indonesia Stock Exchange (IDX). Based on the examination of 93 companies regarding consignment transaction information, this study obtained a final sample of 10 companies. This paper analyzes the application in the consignment income recognition and measurement in retail companies to further examine its suitability with revenue recognition by PSAK 23, 2017.

This study finds that the retail sub-sector companies have some similarities in recording consignment revenues and have obediently made disclosures related to consignment sales revenue following PSAK 23, 2017 even though there was no specific PSAK regulating consignment.
\end{abstract}

Keywords: consignment income; a retail company; revenues

\section{Introduction}

According to Levy and Weitz (2008), retail is a series of business activities to add value to the use of goods and services sold to consumers for personal or household consumption. Meanwhile, Berman and Evans (2012) stated that retailing is a business venture that seeks to market goods and services to end consumers who use them for personal and household purposes. Kotler (2012) stated that retail is a retail sale covering all activities involving the sale of goods or services to end consumers to be used that are personal, not a 
business. Furthermore, Gilbert (2003) stated that retail is all business ventures that direct their marketing capabilities to satisfy end consumers based on the organization of sales of goods and services as the core of distribution. From some of these definitions, it could be concluded that retail includes activities in providing goods needed by end consumers, selling them at reasonable prices, delivering goods to consumers, and convincing consumers that goods sold by retailers could meet consumer needs. One of the retail activities is carried out by retail companies, namely companies that provide products and services that have been given added value to meet personal, family, group and end-user needs. Therefore, retail companies are an important link in the process of distribution of goods and are the last link in the distribution process. Through retail, a product could meet directly with its users. Retail companies use a variety of supply chains to meet market demand.

The products sold are also various, ranging from electronic equipment, clothing, and household needs. In carrying out its business activities, these retail companies use two sales methods, namely selling off and consignment. Recognition of income by breaking up method would certainly be easier in its application because the goods sold are the property of the company unlike the case with consignment sales where goods that exist in retail companies that act as consignees are still the property of the company that entrusts the goods, namely consignors to the goods sold (Waluyo, 2006). In the consignment sales system, consignors and consignees both aim to earn income. Furthermore, the main problems in accounting income are revenue recognition and revenue measurement.

Revenue recognition is a time when a transaction must be recognized as company income, while revenue measurement is how much revenue should be recognized from each transaction that occurs in a certain period. Therefore, income recognition and measurement should be conducted accurately so that the company could present financial statements fairly. If the income recognition and measurement are not precise, then the company's operations would be deemed ineffective and inefficient. Thus, income recognition and measurement have been stipulated in the Statement of Financial Accounting Standards No. 23 (IAI, 2017). The advantage of consignors in the consignment scheme is that there is no need to rent a shop to sell goods. Indeed, this situation leads the consignment scheme attractive to producers. On the other hand, consignors are responsible for product quality, for advertising of their products, because consignees are not responsible for providing advertising services for these products (Yunus and Harnanto, 2013). Consignee does not have a responsibility whether the item is sold or not.

Currently, in Indonesia, there is no specific PSAK that regulates the method of recognizing and measuring consignment sales revenue. Given a large number of consignment sales practices carried out in Indonesia, the specific PSAK on consignment is deemed necessary so that there is uniformity in recognizing consignment revenues from both consignors and consignees. Therefore, the consignment income recognition and measurement could not be separated from PSAK 23 (IAI, 2017) which regulates corporate revenue. Research in Indonesia that reviews consignment is very limited. Rahmawati and Shofianti (2014) reviewed the accounting evaluation of consignment sales at PT Matahari Department Store which concluded that the practice of consignment accounting used by the company was not by generally acceptable accounting treatment. Therefore, this study attempts to review the method of recognition and measurement of consignment sales carried out by retail companies as consignees in Indonesia. This research is essential to be conducted because the practice of consignment could be an illustration of both academics and practitioners regarding accounting discussion. 


\section{Research Methods}

The type of research used is descriptive qualitative research that is by comparing data obtained from observations directly in a company or entity with theories obtained from the literature and then compiled and analyzed. The research aims to obtain a description of the data that could describe the composition and characteristics of the unit under study. The data collected in this study is in the form of qualitative data consisting of secondary data. Secondary data is carried out by determining the object of a retail company registered on the Indonesia Stock Exchange because it is considered to have a consignment transaction. Based on the testing of the financial statements of the 93 retail companies, 10 (ten) companies have obtained consignment transactions with other parties. Furthermore, this research checks the method used in recording income in the company related to consignment revenue. To find and collect data for this study, the analytical techniques used are as follows: (1) Disclosures in Financial Statements. (2) Revenue Measurement by comparing the measurement of income of 10 (ten) retail companies listed on the Indonesia Stock Exchange and the conformity of the Statement of Financial Accounting Standards Number 23. (3) Revenue Recognition by comparing revenue recognition applied by 10 (ten) retail companies listed on the Indonesia Stock Exchange and their suitability with Statement of Financial Accounting Standards Number 23.

\section{Results And Discussion}

The analysis is based on a sample of 10 (ten) financial statements of retail companies listed on the Indonesian Stock Exchange that have been audited with an unqualified opinion for 2017. The deeper analysis of the company's financial statements has been conducted to overview the method of recording in the recognition and disclosure of consignment sales revenue from all financial statements both on the balance sheet, income statement, cash flow statement, report on changes in equity, and notes to financial statements. Summary of disclosure of consignment income explicitly in the income statement and notes to financial statements are shown in Table 1.

Table 1 Disclosure of consignment income on financial statements

\begin{tabular}{|c|c|c|c|c|c|}
\hline \multirow[b]{2}{*}{ No } & \multirow[b]{2}{*}{ Company Name } & \multicolumn{2}{|c|}{ Income Statements } & \multicolumn{2}{|c|}{ Notes to Financial Statements (NFS) } \\
\hline & & $\begin{array}{l}\text { Consignment } \\
\text { sales } \\
\text { commission }\end{array}$ & $\begin{array}{l}\text { Consign } \\
\text { ment } \\
\text { sales - } \\
\text { consignm } \\
\text { ent Out }\end{array}$ & $\begin{array}{l}\text { Inventories } \\
\text { do not } \\
\text { include } \\
\text { consignment } \\
\text { inventories }\end{array}$ & $\begin{array}{l}\text { Revenue from consignment } \\
\text { sales commissions is } \\
\text { recorded in the number of } \\
\text { sales of consignment goods } \\
\text { to customers less the } \\
\text { amount owed to consignors }\end{array}$ \\
\hline 1 & PT Electronic City Tbk & $\sqrt{ }$ & & & $\sqrt{ }$ \\
\hline 2 & PT Ace Hardware Indonesia Tbk & & $\sqrt{ }$ & & \\
\hline 3 & PT Supra Boga Lestari Tbk & $\sqrt{ }$ & & $\sqrt{ }$ & $\sqrt{ }$ \\
\hline 4 & PT Ramayana Lestari Sentosa Tbk & $\sqrt{ }$ & $\begin{array}{l}\sqrt{ } \text { (Notes } \\
\text { to FS) }\end{array}$ & & $\sqrt{ }$ \\
\hline 5 & PT Matahari Putra Prima Tbk & $\begin{array}{l}\sqrt{ } \text { (Notes to } \\
\text { FS })\end{array}$ & $\begin{array}{l}\sqrt{ }(\text { Notes } \\
\text { to FS) }\end{array}$ & $\sqrt{ }$ & $\sqrt{ }$ \\
\hline 6 & PT Multipolar Tbk & & & $\sqrt{ }$ & $\sqrt{ }$ \\
\hline 7 & PT Mitra Adiperkasa Tbk & $\sqrt{ }$ & & & $\sqrt{ }$ \\
\hline 8 & PT Matahari Department Store Tbk & & $\sqrt{ }$ & & $\sqrt{ }$ \\
\hline 9 & PT Hero Supermarket Tbk & & $\sqrt{ }$ & & $\sqrt{ }$ \\
\hline 10 & PT Catur Sentosa Adiprama Tbk & & $\sqrt{ }$ & & \\
\hline
\end{tabular}


After analyzing the disclosure of consignment sales transactions conducted by retail companies in their financial statements as disclosed in Table 1, there are some similarities in the disclosures made by the retail company. The first similarity is the disclosure of the consignment sales commission in the income statement and the second is the disclosure of the method used by the company as disclosed in the Notes to the Financial Statements. Generally, there are 3 (three) methods used in recording revenue from consignment sales commissions, namely: (1) by using a "commission sales consignment" account which is income from the commission of net consignment sales received by retail companies as consignees, (2) there is a separation between the account "consignment sales minus consignment expenses" which results in the amount of "consignment income". The consignment sales account here contains the total sales of consigned goods carried out by the consignee. Whereas the consignment expenses are the amount owed to the owner (consignor), and (3), there is a company that directly combines all of its income in the income account (including consignment income), namely PT Matahari Putra Prima Tbk. Furthermore, in the Notes to the Financial Statements, it is explained about the consignment income recognition. In the end the method of recording results in the same amount of income recognized by the consignee for consignment sales, that is equal to the net value of the commission received by the consignee or the value of consignment sales minus the consignment expenses.

Also, there are $30 \%$ (thirty percent) of companies disclosing "inventories are not included in consignment inventories," while the rest are not found in the notes to their financial statements. This finding indicates that the consignee does not include the consignment inventory as inventory. Accordingly, it is by the provision that consignment goods are still goods belonging to the consignor as long as no sale has been made so that the consignee has no right to recognize the consignment inventory as its inventory.

Other information, $80 \%$ (eighty percent) of companies disclose "the revenue from the consignment sales commission is recorded at the number of sales of consignment goods to customers minus the amount owed to the consignor," while the remaining information is not found in the notes to the financial statements. This explicitly states that what is recognized as consignment sales revenue is the consignment sales commission, for example, the amount sold to the customer is reduced by the amount owed to the consignor. Accordingly, it is by the provision of income recognition that the amount of consignee income is the net amount of consignment income.

Furthermore, the comparison between conditions that should be met in revenue recognition under PSAK 23 (IAI, 2017) and their suitability in the financial statements used as research objects are shown in Table 2.

From the analysis of financial statements, it could be considered that the income measurement from the consignment sales commission is recorded at the number of sales of consignment goods to the customer minus the amount owed to the consignor. This also reveals that the income is recognized when there is an income, namely economic benefits that go to the consignee as a result of sales made to the buyer. Thus, the provisions of PSAK 23 (IAI, 2017) are fulfilled. This study completes Rahmawati and Shofianti (2014). Furthermore, 
the determination of when the entity has transferred the risks and benefits of ownership significantly to the buyer requires examining the condition of the transaction. In general, the transfer of risks and benefits of ownership occurs at the same time as the transfer of ownership or control over the item to the buyer. In this case, the new income is recognized by the consignee when the consignment item is successfully sold to the buyer. As long as the item has not been sold, even though the consignee is still the consignor. It is relevant the disclosure in the Notes to the Financial Report "Inventories do not include consignment inventories." The disclosure indicates that the value of inventory assets reported by the consignee includes only assets that are the property of the consignee, excluding consignment inventories. Consignment inventories are reported in consignor inventories.

Table 2 Suitability of research objects with PSAK 23 (IAI, 2017)

\begin{tabular}{|c|c|c|}
\hline No & $\begin{array}{c}\text { Conditions that must be met in revenue } \\
\text { recognition }\end{array}$ & Conformity with the object of research \\
\hline 1 & $\begin{array}{l}\text { The entity has transferred the risks and benefits of } \\
\text { ownership of goods significantly to the buyer; }\end{array}$ & $\begin{array}{l}\text { Confirmed. } \\
\text { Income is recognized when a sale has occurred to } \\
\text { the buyer, not when the submission from the } \\
\text { consignor to the consignee }\end{array}$ \\
\hline 2 & $\begin{array}{l}\text { The entity no longer continues the management } \\
\text { which is usually related to ownership of goods or } \\
\text { makes effective control of goods sold; }\end{array}$ & $\begin{array}{l}\text { Confirmed. } \\
\text { Goods management is no longer conducted when } \\
\text { goods have been sold to buyers }\end{array}$ \\
\hline 3 & The amount of income could be measured reliably; & $\begin{array}{l}\text { Confirmed. } \\
\text { Amount of payment from the buyer to seller. } \\
\text { Consignee income = commission on consignment } \\
\text { sales (consignment sales - consignment expenses) } \\
\text { Consignor income = income from consignee }\end{array}$ \\
\hline 4 & $\begin{array}{l}\text { It is likely that the economic benefits associated with } \\
\text { the transaction would flow to the entity; and }\end{array}$ & $\begin{array}{l}\text { Confirmed. } \\
\text { Consignment sales revenue. For retail companies, } \\
\text { the majority of sales are made in cash. }\end{array}$ \\
\hline 5 & $\begin{array}{l}\text { Expenses incurred or that would occur regarding the } \\
\text { sales transaction could be measured reliably }\end{array}$ & $\begin{array}{l}\text { Confirmed } \\
\text { Consignment expenses as disclosed in the Notes to } \\
\text { Financial Statements }\end{array}$ \\
\hline
\end{tabular}

\section{Conclusions and Suggestion}

A. Conclusions

Practices carried out by retail companies in their financial statements are related to consignment sales revenue, there are 4 (four) conclusions. First, there is currently no Financial Accounting Standards Statement in Indonesia that specifically regulates consignment. Second, although there is no specific PSAK that regulates consignment, in practice retail companies have obediently made disclosures related to consignment sales revenue. Recognition of the income is by PSAK Number 23. Third, revenue from the consignment sales commission is recorded at the number of sales of consignment goods to the customer minus the amount owed to the consignor. This is in accordance with the conditions that should be met in revenue recognition, namely: a) the entity has transferred the risks and benefits of ownership of goods significantly to the buyer; $b$ ) the entity no longer continues management which is usually related to ownership of goods or makes effective control of goods sold; c) the amount of income could be measured reliably; d) it is probable that the economic benefits associated with the transaction would flow to the entity; and e) costs incurred or that would occur regarding the sale transaction could be measured reliably. Under these conditions, consignment revenue is recognized after the goods have been sold from the consignee to the 
buyer, not when the delivery from the consignor to the consignee occurs. It is appropriate as revealed in the financial statements that the consignment sales commission is recognized when a sale has taken place and costs could be measured reliably. Finally, the amount of inventory listed in the consignee balance sheet does not include consignment inventories. This is consistent with the concept that consignment goods are still consignor's property up to the time of sale to the buyer.

\section{B. Suggestion}

This study has a major limitation that lies in the results of research that has a high level of generalization. Sampling on the object of this study was carried out not randomly selected, so the amount of the sample is limited. This research is expected to contribute and suggest to the Indonesia Accounting Standards Board to consider the arrangement of specific rules regarding the consignment transaction because the companies still rely on PSAK 23, 2017 for the recognition and measurement of consignment sales. However, that PSAK not specifically regulates about consignment. Furthermore, for the parties involved in the consignment mechanism, a precautionary principle is needed in income recognition in consignment sales because consignors use various systems and accounts to record consignment sales so as not to violate various conditions in recognition of income set out in PSAK 23, 2017.

\section{References}

Berman, B., \& Evans, J.R. (2012). Retail Management: A Strategic Approach (12 ${ }^{\text {th }}$ Edition). New Jersey: Prentice Hall.

Gilbert, D. (2003). Retail Marketing Management. New Jersey: Prentice Hall.

Ikatan Akuntansi Indonesia (IAI). (2017). Pernyataan Standar Akuntansi Keuangan No. 23: Pendapatan. Jakarta: Dewan Standar Akuntansi Keuangan Ikatan Akuntan Indonesia.

Kotler, P. (2012). Marketing Management (14th Edition). New Jersey: Prentice Hall.

Levy, M., \& Weitz, B. (2008). Retailing Management (7 ${ }^{\text {th }}$ Edition). Boston: Irwin/McGraw-Hill.

Rahmawati, I.D., \& Shofianti, W. (2014). Evaluasi akuntansi penjualan konsinyasi dan penyajiannya pada laporan laba rugi PT Matahari Department Store Sidoarjo. Jurnal Analisa, 3(2): 59-71.

Waluyo, J. (2006). Akuntansi Keuangan Lanjutan I (Edisi Revisi). Malang: Universitas Muhammadiyah Malang.

Yunus, H., \& Harnanto. (2013). Akuntansi Keuangan Lanjutan. Yogyakarta: BPFE. 